\title{
MASA DEPAN CIVIL SOCIETY DI INDONESIA: PROSPEK DAN TANTANGAN
}

\author{
Halili \\ Dosen Pendidikan Hak Asasi Manusia pada Jurusan Pendidikan \\ Kewarganegaraan dan Hukum FISE UNY
}

\begin{abstract}
This paper aims to discuss on civil society, its prospects and challenges. It is ungent because civil society is a determining factor of Indonesia democratization.

Civil society is a society within staie wbich containing social association which bas ability to fill public spaces between state and citizen, and interact with state independily, wether indivual or collective. Prospect of civil society forming is determined by establishment of some components: 1) existence of societal autonomy, 2) access of public to state agencies, 3) independent public areno, 4) arena publik yang mandiri, dan keempat arena publik yang terbuka. Prospect of civil society development is influenced by optimalization of some factors: 1) establisbment of democratic families, 2) growth of roles of non government onganization toward both state and citizen, 3) increase of intellectual middle class, especially students, and 4) implementation of political education formally (eg. civic or citizenship education) and informally. The challenges offuture of civil society are: 1) bigb of social fragmentation among people, 2) limited distribution of development results in field of economy, social, and education, and also 4) paternalistic culture which is still strong among society.
\end{abstract}

Keyzeord:Civil Society, State, Prospect, Challange

\section{Pendahuluan}

Sampai saat ini wacana civil society masih dan selalu aktual untuk dibicarakan, sebab wacana tersebut dalam posisi beriringan dengan bergulirnya isu demokratisasi dalam penyelenggaraan negara-negara di dunia, terutama negaranegara dimana tingkat demokratisasi di dalamnya masih rendah, baik di bidang politik, ekonomi, maupun sosial. Pembicaraan tentang civil society mengemuka di Indonesia sejak tahun 1990-an, setelah sebelumnya terjadi proses perubahan pendekatan dalam ilmu politik mulai tahun 1970-an dari legal formal ke pendekatan behavioralisme (pendekatan perilaku atau pendekatan sistemik), dan bergeser lagi ke pendekatan struktural, khususnya di dalam politik ekonomi. Civil society yang 
begitu kental mengisi ruang publik membuat wacana ini menembus batas keilmuan, sehingga civil society seringkali diberi batasan yang kurang pas dan dipahami dalam interpretasi kurang benar.

Dalam konteks Indonesia dimana proses demokratisasi terus berjalan civil society merupakan sebuah cita-cita politik, walaupun pada perjalanannya sampai saat ini pencapaian tujuan tersebut bukan sesuatu yang mudah. Sosialisasi politik di Indonesia yang diantaranya melahirkan pendidikan politik belum memberikan space yang cukup untuk berkembangnya civil society (Afan Gaffar, 2000: 118).

$\mathrm{Hal}$ itu, antara lain disebabkan oleh kondisi dimana anak-anak dalam keluarga, tidak terdidik untuk menjadi elemen keluarga yang mandiri. Anak-anak bahkan mengalami alienasi dalam politik keluarga dimana acapkali keputusan penting yang diambil oleh keluarga termasuk di dalamnya keputusan tentang kepentingan anak itu sendiri menjadi dominasi orang dewasa. Selain itu, tingkat politisasi masyarakat di Indonesia masih sangat rendah. Sebagian besar masyarakat kita, terutama golongan menengah dan bawah masih melihat bahwa ikut terlibat dalam wacana publik tentang hak-hak dan kewajiban warga negara, hak asasi manusia dan sejenisnya bukanlah merupakan skala prioritas yang penting. Dengan kondisi demikian, sosialisasi politik masyarakat baru sampai pada dataran kognitif, belum menyangkut dimensi-dimensi yang bersifat evaluatif atas isu-isu politik yang berkembang dalam masyarakat itu sendiri. Kondisi demikian berpengaruh terhadap proses pengembangan civil society di Indonesia.

Maka dari itu, sangat relevan diskusi tentang pengembangan civil society di Indonesia menyusul bergulirnya reformasi dan keterbukaan yang mewarnai kehidupan sosial politik di Indonesia, serta di berbagai bidang lainnya.

\section{Tinjauan Dialektis tentang Civil Society}

Ilmu politik sebagai bagian dari ilmu sosial banyak memiliki perspektif dalam memahami sesuatu, termasuk konsep tentang civil society. Beberapa pakar memberikan gambaran dan batasan tentang civil society. Victor Perez-Diaz dalam Hall (1995: 18) tentang hal ini mengatakan bahwa civil society adalah bagian institusional yang terdiri dari kombinasi pengaturan politik dan ekonomi sebagai berikut: pemerintahan yang terbatas dan dijalankan dengan penegakan hukum, ekonomi pasar, susunan kebebasan, asosiasi-asosiasi sukarela di bidang politik, ekonomi, sosial dan budaya, serta ruang debat publik yang bebas. Dalam hal ini dia menekankan civil society pada kondisi masyarakat yang di dalamnya terdapat kewenangan pemerintah yang terbatas, kebebasan ekonomi pasar, dan munculnya asosiasi-asosiasi masyarakat yang mandiri, dimana satu sama lain saling menopang. 
Sementara itu, Christopher Bryant dalam buku yang sama mengatakan bahwa civil society terkait dengan masyarakat yang beradab (civilized) dan berseberangan dengan masyarakat primitif yang barbar dan liar. Selanjutnya ia mengatakan bahwa asosiasi politik adalah sekolah-sekolah demokrasi yang bebas, mereka mengadakan pelajaran-pelajaran di dalam asosiasi-asosiasi seni. Warga negara belajar untuk bertukar pandangan, mengorganisir, dan melindungi otonomi mereka untuk menjaga penilaian yang independen terhadap pemerintah atas segala hal dimana penyebaran informasi dan pandangan-pandangan oleh surat kabar dan media lain sangatlah krusial.

Pendapat yang lain tentang civil society dikemukakan oleh Nicos Mouzelis. Dia mendefinisikan bahwa civil society adalah semua kelompok sosial dan lembaga sosial, dalam sebuah tatanan sosial, yang muncul di tengah-tengah ikatan kelompokkelompok primordial dan institusi-institusi lainnya. Yang dimaksudkan tatanan sosial dalam paparan tersebut adalah adanya perbedaan yang jelas antara bidang pribadi dan bidang publik, serta adanya tingkat mobilitas sosial yang tinggi yang dilakukan oleh warga masyarakat. Elemen-elemen civil society menurut Mouzelis antara lain:

1. Adanya penegakan hukum yang secara efektif melindungi kepentingan warga negara dari kesewenang-wenangan negara ;

2. Adanya kelompok kepentingan yang dikelola secara kuat, yang mampu melakukan pengawasan atas penyalahgunaan kekuasaan yang dilakukan oleh mereka yang memegang kontrol atas sarana-sarana administrasi dan saranasarana pemaksa ;

3. Adanya pluralisme yang seimbang di antara kepentingan-kepentingan masyarakat yang tidak membuka peluang adanya kelompok dominan mutlak.

Dapat dikatakan pula bahwasanya civil society pada hakekatnya adalah sebuah ruang yang terletak antara negara dan masyarakat, dan di dalam ruang tersebut terdapat asosiasi-asosiasi warga masyarakat secara sukarela dan di antara asosiasiasosiasi tersebut terbangun jaringan yang kuat. Civil society merupakan suatu bentuk hubungan antara negara dengan sejumlah kelompok sosial yang sifatnya independen terhadap negara.

Dari beberapa pendapat tersebut dapat disimpulan bahwa civil society adalah masyarakat dalam negara yang di dalamnya terdapat asosiasi-asosiasi sosial yang mampu mengisi ruang publik antara masyarakat dengan negara serta berinteraksi dengan negara secara independen, baik secara individual maupun kolektif.

Menurut Eissenstadt dalam Lipset sebagaimana dikutip oleh Afan Gaffar (2000: 180), masyarakat yang dimaksud memiliki beberapa komponen yang 
meliputi: Pertama, otonomi. Otonomi yang dimaksudkan disini adalah keterlepasan masyarakat dari pengaruh negara, baik dalam bidang ekonomi, politik, maupun sosial. Dalam kondisi demikian, segala inisiatif dan bentuk kegiatan masyarakat sepenuhnya bersumber dari masyarakat itu sendiri, tanpa ada campur tangan dari negara. Masyarakat dapat mengadakan kegiatan ekonomi dengan leluasa, sedangkan negara hanya menjadi fasilitator bagi kegiatan ekonomi yang dilakukan oleh masyarakat, misalnya melakukan regulasi untuk mengatur persaingan dalam kegiatan ekonomi dan melindungi kepentingan publik, dimana publik atau masyarakat itu terlibat sepenuhnya di dalam kegiatan tersebut. Jika seseorang akan membuka suatu usaha industri, misalnya, negara diharapkan ikut andil dalam hal memberikan perlindungan kepentingan di sekitar lingkungan usaha tersebut. Atau kalau seorang pemeluk agama ingin mendirikan tempat ibadah maka dengan sendirinya negara akan terlibat. Karena fungsi negara dalam hal ini adalah menjaga keseimbangan sosial, terutama di antara kelompok masyarakat yang ada.

Jadi, makna yang paling substansial dari otonomi dalam civil society ini adalah kemandirian dalam mengambil inisiatif untuk melakukan kegiatan, serta kemandirian dari intervensi negara yang tidak seharusnya dilakukan. Demikian juga kemandirian dalam bidang politik. Organisasi politik, seperti parta-partai politik, organisasi massa, kelompok kepentingan dan kelompok penekan, dapat melakukan kegiatan apa saja sepanjang yang dilakukan tersebut tidak bertentangan dengan hukum yang berlaku. Partai politik dan kelompok kepentingan boleh melakukan kongres, muktamar, musyawarah nasional, dan atau kegiatan apa saja. Semua kekuatan politik dapat melaksanakan rekrutmen politik. Bila mereka mau memilih pemimpinnya dapat saja mereka lakukan sesuai dengan kehendak mereka. Campur tangan negara dalam hal ini sangatlah terbatas.

Kedua, akses masyarakat terhadap lembaga negara. Dalam konteks hubungan antara negara dengan masyarakat, setiap warga negara baik secara individual maupun kolektif, harus mempunyai akses terhadap agen-agen pemerintahan. Artinya individu dapat melakukan berbagai bentuk partisipasi politik, misalnya dengan menghubungi pejabat pemerintah untuk menyampaikan aspirasi dan keluahn-keluhan, menulis pikiran pembaca di surat kabar atau media lain, atau terlibat secara aktif baik langsung maupun tidak langsung dalam organisasi politik yang ada. Atau bahkan dengan cara unjuk rasa untuk menarik simpati dan perhatian publik secara lebih luas. Dan di lain pihak, negara harus memiliki komitmen untuk mendengar, menerima keluhan dan aspirasi warganya, dan diteruskan dengan mengambil sejumlah langkah-langkah konkrit untuk merealisasikan aspirasi dan keluhan warganya. 
Ketiga, arena publik yang bersifat mandiri. Arena publik disini adalah sebuah ruang dimana warga negara mengembangkan dirinya secara maksimal dalam segala aspek kehidupan, bidang ekonomi atau bidang lainnya. Kegiatan-kegiatan mereka di bidang ekonomi, keagamaan, dan politik dapat dengan leluasa dilakukan. Arena publik ini pada dasarnya terlepas dari campur tangan negara, apalagi elemenelemen negara yang bersifat koersif. Sekalipun demikian, kalangan masyarakat yang bersifat independen ini harus mampu membuka kesempatan kepada negara agar bisa melakukan akses terhadap mereka. Sehingga, organisasi-organisai sosial yang bersifat mandiri tersebut relatif memiliki tingkatan penerimaan yang tinggi terhadap aturan-aturan dasar permainan politik. Dalam konteks ini, negara dan masyarakat saling mengakui otoritas masing-masing. Di satu pihak negara tidak sewenang-wenang memaksakan kehendaknya terhadap masyarakat, di pihak yang lain, masyarakat juga tidak boleh memilih jalan yang anarkis di dalam menyampaikan kehendak dan aspirasi mereka. Selain dengan negara, hubungan antar sesama asosiasi sosial pun harus seimbang. Tidak ada asosiasi sosial yang dapat memonopoli segala kewenangan, serta memaksakan otoritasnya kepada asosiasi sosial yang lain, apalagi melakukan negasi terhadap eksistensi asosiasi sosial yang lain.

Keempat, Arena publik yang terbuka. Arena publik dalam civil society terbuka bagi semua lapisan masyarakat, tidak dijalankan dengan cara-cara yang eksklusif, bersifat rahasia, dan korporatif. Masyarakat dapat mengetahui apa saja yang yang terjadi di sekitar lingkungan kehidupannya, bahkan ikut terlibat di dalamnya. Diskusi yang bersifat terbuka yang menyangkut masalah publik, merupakan suatu keharusan. Sehingga, kebijaksanaan publik tidak hanya melibatkan sekelompok kecil orang saja.

\section{Prospek dan Tantangan Pengembangan Civil Society di Indonesia}

Analisis tentang prospek pengembangan civil socieíy di Indonesia bukanlah sesuatu yang mudah mengingat kompleksitas faktor yang mempengaruhinya. Selanjutnya, prospek tersebut dapat dianalisis dengan mengacu pada komponenkomponen civil society sebagaimana telah dipaparkan penulis pada bagian sebelumnya; Otonomi, akses masyarakat terhadap lembaga negara, Arena publik yang mandiri dan arena publik yang terbuka.

Pertama, ditinjau dari aspek komponen civil society yang pertama; otonomi. Masyarakat Indonesia sedikit demi sedikit sudah mulai mengalami transformasi dari masyarakat yang sama sekali sangat tergantung kepada negara pada era Orde Baru ke arah minimalisasi atau pembatasan-pembatasan pengaruh negara dalam 
kegiatan-kegiatan masyarakat pada era pasca Orde Baru. Ketergantungan masyarakat terhadap pemerintahan negara pada masa Orde Baru disebabkan oleh dua faktor, internal dan eksternal. Secara internal masyarakat memiliki ketergantungan terhadap negara disebabkan oleh kegiatan pembangunan yang dicanangkan oleh pemerintah, sehingga mau tidak mau masyarakat masuk ke dalam wilayah pengaruh negara karena kebutuhan mereka akan pemenuhan kepentingan dan kebutuhan mereka sendiri. Contoh konkrit dalam hal ini adalah kebijakan IDT yang dikeluarkan oleh pemerintah, menyebabkan masyarakat secara sukarela menggantungkan diri pada negara karena hal itu mereka rasakan sangat krusial untuk pengembangan daerah dan pemenuhan kepentingan lain mereka, terutama dalam masyarakat yang terbelakang secara vertikal dan horizontal.

Selain itu, mereka juga dipengaruhi oleh faktor eksternal masyarakat, dalam hal ini adalah negara. Pada masa Orde Baru pemerintah memiliki kekuatan sistematik dalam koridor yuridis formal dan administrasi penyelenggaraan negara yang memaksa warga masyarakat untuk tergantung kepada negara, meskipun secara terpaksa. Hal demikian membuat kekuasaan negara begitu kuat dan dominan atas kekuasaan masyarakat sebagai sub ordinatnya. Dalam hal ini campur tangan negara terhadap kegiatan-kegiatan masyarakat sangat besar, dan tidak jarang negara mengeluarkan kebijakan-kebijakan etatis dan menggunakan tindakan-tindakan represif dalam mengontrol dan mengawasi kegiatan masyarakat. Salah satu tragedi yang mengingatkan kita akan betapa besarnya kekuasaan pemerintah atas masyarakat saat itu adalah tragedi Tanjung Priuk yang dinilai sebagai salah satu pelanggaran berat hak asasi manusia yang dilakukan oleh negara. Tragedi Waduk Nipah di Madura juga contoh konkrit serupa yang membuktikan kuatnya pengaruh dan campur tangan pemerintah atas kegiatan dan inisiatif masyarakat.

Angin reformasi yang mulai berhembus di Indonesia sejak bulan Mei tahun 1998 meciptakan transformasi otonomi masyarakat vis a vis negara ke tingkat yang jauh lebih baik. Warga masyarakat belakangan ini -terhitung sejak pertengahan 1998 tersebut- mulai menanggalkan ketergantungan besar mereka kepada pemerintah, dan terus berusaha untuk membatasi pengaruh dan campur tangan pemerintah dalam kegiațan-kegiatan masyarakat. Walaupun demikian proses transformasi otonomi masyarakat belum dapat dikatakan sempurna sebagai salah satu komponen civil saciety:

Namun begitu, atmosfer dimana negara sedikit demi sedikit mengurangi penetrasi dominasinya pada wilayah-wilayah privat warga negara akan menjadi salah satu prospek pengembangan civil society yang menjadi salah satu basis demokratisasi di Indonesia. 
Kedua, ditinjau dari komponen civil society yang kedua, yaitu akses masyarakat terhadap lembaga negara. Proses demokratisasi yang sedang berjalan yang melahirkan berbagai bentuk sosialisasi atau pendidikan politik memberikan kemungkinan lebih besar kepada masyarakat untuk memiliki akses terhadap agenagen pemerintahan. Pada prakteknya, lembaga-lembaga negara yang menjalankan eksekutif maupun fungsi-fungsi lainnya belakangan mengalami perubahan, dimana mereka dengan sendirinya sesuai dengan tuntutan situasi dan perkembangan politik riil dalam masyarakat, mulai membuka diri untuk publik yang memungkinkan masyarakat untuk memiliki akses ke dalamnya dalam hal penerimaan informasi sebagai salah satu hak masyarakat, dan dalam hal pemenuhan kepentingan masyarakat dalam kapasitas mereka sebagai pelaksana public services. Titik awal desakralisasi lembaga pemerintahan secara institusional maupun personal dilakukan oleh Presiden Habibie, dilanjutkan oleh Presiden KH. Abdurrahman Wahid, dengan membuka istana negara kepada masyarakat agar mereka memiliki akses yang cukup terhadap salah satu lokasi lembaga pemerintahan tersebut.

Akses masyarakat terhadap lembaga negara belakangan sudah dilakukan dengan cukup baik oleh warga masyarakat, misalnya ditunjukkan dengan mendatangi lembaga pemerintahan untuk menyampaikan aspirasi atau sekedar untuk mendapatkan informasi. Bentuk akses yang lain terhadap lembaga-lembaga negara antara lain dengan melakukan bearing dengan anggota legislatif di DPR atau DPRD. Unjuk rasa atas kebijakan lembaga pemerintahan yang dalam pandangan masyarakat dianggap kurang memenuhi aspirasi masyarakat, merupakan salah satu indikasi bahwa pada dasarnya masyarakat memiliki akses yang cukup bagus terhadap lembaga pemerintahan.

Jika aktivitas tersebut terus dipelihara, maka akan menjadi salah satu penopang bagi terciptanya civil society sebagai salah satu elemen demokratisasi.

Ketiga, ditinjau dari komponen dari civil society yang ketiga, yaitu arena publik yang mandiri. Arena publik yang berbentuk organisasi-organisasi sosial dan organisasi-organisasi politik memiliki tingkat kemandirian yang relatif rendah. Dimana, pada kenyataannya partai politik, kelompok penekan, dan organisasi politik lainnya secara finansial belum bisa mandiri terlepas dari arrangement yang dilakukan oleh negara. Di sisi yang lain akselerasi peran yang mereka tunjukkan belum seimbang dengan kewenangan negara yang memiliki daya tawar yang relatif lebih tinggi. Walaupun secara formal, otoritas negara dengan otoritas organisasi sosial-politik, partai politik misalnya, dalam permukaannya tampak seimbang, akan tetapi pada pelaksanaannya daya tekan pemerintah atas partai politik lebih kuat. 
Selain itu, organisasi sosial dan politik-seperti partai politik dan kelompok kepentingan - sebagai sebuah arena publik juga masih memiliki tingkat kemandirian yang sangat rendah, paling tidak dalam dua hal; pertama, menyangkut derajat rekruitmen yang mereka miliki, kedua, derajat aktivitas yang memungkinkan mereka mengisi ruang yang tersedia antara negara dan masyarakat.

Dari sudut pandang rekrutmen politik yang dilakukan oleh partai politik, misalnya dalam hal penentuan calon legislatif yang berorientasi pada kekuasaan negara tidak sepenuhnya dilandaskan pada kemandirian dan representasi masyarakat konstituennya. Keterlibatan banyak partai politik dalam pemerintahan secara otomatis memperkuat kecenderungan keberpihakan mereka kepada kepentingan pemerintah, bukan pada masyarakat. Selain itu, dari sudut pandang aktivitas mereka dalam mengisi ruang publik yang tersedia antara masyarakat dan negara, tampaknya masih berat pada keberpihakan pada negara daripada kepentingan masyarakat dalam sekup yang lebih luas. Hal itu, disebabkan oleh karena sejak kelahirannya partai politik sulit dilepaskan dari orientasi awalnya untuk meraih kekuasaan. Maka, dalam konteks ini sebenarnya ada dua kemungkinan yang dilakukan oleh partai politik, yaitu berada dalam jalur utama pemerintahan, atau jika meraka tersingkir dan tidak mampu berada di jalur tersebut, maka akan memposisikan diri dalam oposisi.

Organisasi sosial lainnya baik yang berorientasi politik maupun tidak, yang bergerak di bidang profesi misalnya SPSI, IDI dan PGRI, kelompok kepentingan yang merupakan representasi kepentingan tertentu seperti kadin, dan kelompok keagamaan seperti NU, Muhammadiyah, dan walubi sampai saat ini belum memiliki derajat aktivitas yang mampu mengisi ruang publik secara independen. Organisasi sosial yang mungkin sangat mungkin untuk diharapkan berperan secara independen sebagai arena publik yang mandiri adalah Lembaga Swadaya Masyarakat dan media massa, khususnya media cetak.

Keempat, ditinjau dari sudut pandang komponen civil society yang terakhir, yaitu arena publik yang terbuka. Heterogenitas dan pluralisme, serta tingginya fragmentasi sosial bangsa Indonesia turut memberikan kendala alami dalam penciptaan arena publik yang terbuka. Seperti diketahui, klasifikasi kelompok masyarakat di Indonesia yang ada selama ini didasarkan pada ikatan-ikatan primordial, yang hal itu menyebabkan rendahnya tingkat inklusivitas asosiasi sosial dalam masyarakat. Kondisi demikian, menyebabkan kerentanan untuk terciptanya konflik horizontal antar asosiasi sosial masyarakat.

Masih hangat tentunya dalam rekaman memori masyarakat Indonesia, kentalnya nuansa ekslusivitas asosiasi-asosiasi sosial di dalam masyarakat dalam 
merespon pro kontra seputar Rancangan Undang-Undang tentang Sistem pendidikan Nasional yang akhirnya disahkan oleh DPR menjadi UU. Begitu pula asosiasi-asosiasi sosial yang berkepentingan di dalam merespon pro kontra seputar proses spin off PT. Semen Padang dari PT. Semen Gresik. Hal itu membuktikan bahwa kepentingan-kepentingan ikatan primordial dalam asosiasi sosial merupakan ancaman bagi terciptanya keterbukaan arena publik, jika tidak dikelola secara dewasa atas dasar kebersamaan dalam bingkai kebangsaan.

Di samping itu prospek pengembangan civil society, bisa dibangun dari beberapa pilar, di antaranya: Penciptaan keluarga demokratis, peningkatan peran organisasi non pemerintah, optimalisasi peran kelas menengah intelektual, khususnya mahasiswa, dan pendidikan politik, yang satu persatu dideskripsikan sebagaimana berikut.

Pengembangan civil society di Indonesia dalam tahap yang sangat mendasar bisa diawali dari keluarga, yang dalam terminologi Anthony Giddens (2000: 102) disebut keluarga demokratis. Keluarga merupakan institusi dasar dalam pengembangan civil society. Penciptaan keluarga demokratis harus dimulai dari langkah yang paling fundamental, yaitu prinsip kesamaan derajat antar jenis kelamin, dan bukan berarti kesamaan fungsi dan peranan.

Kriteria demokrasi di dalam keluarga tidak jauh berbeda dengan kriteria demokrasi dalam ruang publik yang lebih luas. Kriteria dalam ruang publik paling tidak melibatkan kesamaan formal, hak-hak individual, diskusi publik tentang berbagai isu tanpa kekerasan, dan otoritas yang merupakan output dari negosiasi, bukan diwariskan oleh tradisi.

Demokratisasi dalam keluarga berimplikasi pada kesetaraan, otonomi, pengambilan keputusan melalui komunikasi, dan kebebasan dari kekerasan. Karakteristik yang serupa juga mengisi model hubungan antara orang tua dan anak. Penanaman karakteristik demokrasi dalam keluarga akan berimplikasi dalam jangka panjang terhadap penciptan demokrasi dalam ruang publik yang lebih luas.

Aspek lain yang sangat mungkin untuk diharapkan peranannya dalam pengembangan civil society di Indonesia adalah LSM. Di tengah kondisi organisasi politik, seperti partai politik dan kelompok kepentingan atas dasar profesi tidak terlalu dapat diharapkan untuk saat ini, maka LSM dalam wacana politik Indonesia bisa mengisi ruang publik yang independen dalam civil society. Partisipasi yang dilakukan oleh LSM selama ini bersifat dua arah. Arah pertama, adalah partisipasi dalam meningkatkan kualitas masyarakat. Peningkatan kualitas masyarakat tersebut dilakukan dengan memberikan pendidikan sosial dan politik kepada masyarakat, baik secara langsung maupun tidak langsung. Sedangkan arah yang kedua, adalah 
partisipasi dalam mengisi ruang publik dalam hubungan antara masyarakat dengan negara. Contoh konkrit dari partisipasi dua arah tersebut adalah apa yang selama ini dilakukan oleh PBHI, YLKI, YLBHI, Walhi, Lapera dan sebagainya.

Pengembangan civil society tampaknya juga tidak bisa dilepaskan dari peran dan keterlibatan mahasiswa kini dan pada masa-masa yang akan datang. Runtuhnya hegemoni kekuasaan Orde Baru dan bergulirnya bola reformasi tidak bisa dilepaskan dari peranan mahasiswa. Peranan demikian harus terus dikembangkan oleh kelas menengah intelektual tersebut, bukan saja pada wilayah partisipasi politik terhadap kebijakan-kebijakan publik oleh pemerintah, akan tetapi juga dalam rangka peningkatan kualitas kehidupan masyarakat, untuk mengembangkan civil society di Indonesia.

Salah satu jalan lain menuju pengembangan civil society di Indonesia adalah penyelenggaraan pendidikan politik bagi warga negara secara sistematis melalui kegiatan-kegiatan formal, serta di sisi yang lain menegasikan doktrin-doktrin ideologi politik pemerintah. Selama bertahun-tahun pemerintah memaksakan doktrin ideologi politik pemerintah yang dibungkus dalam pendidikan formal, seperti P-4 dan PMP, sebagai bentuk campur tangan negara yang bersifat etatis. Apalagi indoktrinasi tersebut disertai dengan ancaman-ancaman yang bersifat represif dengan alasan subversi.

Pendidikan politik dalam pendidikan formal harus dipandang sebagai salah satu hak warga negara dalam rangka peningkatan politics literacy dan partisipasi politik. Dalam hal ini, pendidikan politik bisa dikemas dalam format pendidikan kewarganegaraan seperti di negara-negara demokrasi maju yang dikenal dengan terminologicivic education atau citizenship.

Namun begitu begitu banyak prospek yang memungkinkan terwujudnya civil society tidak serta merta meniscayakan kemudahan pada implementasinya di lapangan, hal itu mengingat seluruh prospek yang ada pasti lahir bersama tantangan. Tantangan tersebut diantaranya adalah tingginya fragmentasi sosial, belum meratanya hasil pembangunan, dan masih kuatnya budaya politik paternalistik.

Masyarakat Indonesia adalah masyarakat yang sangat pluralistik atau bisa juga dikatakan sebagai masyarakat yang sangat tinggi fragmentasi sosialnya dipandang "dari berbagai aspeknya: Itu semua merupakan sesuatu yang bisa menghambat tumbuh dan berkembangnya civil society, atau paling tidak memperlambat perkembangan tersebut.

Keterlepasan masyarakat yang sudah mulai ada masih akan terus bergulir secara gradual, sampai saat ini masih sampai pada tingkatan yang rendah, terutama di bidang ekonomi dan politik. Krisis ekonomi yang tidak kunjung selesai menerpa 
Indonesia, membuat ketergantungan masyarakat masih sangat besar. Krisis ekonomi yang alah satu eksesnya adalah menurunnya income penduduk Indonesia per tahun per kapita secara menyeluruh semakin memperparah ketergantungan masyarakat kepada pemerintah melalui subsidi-subsidi. Ketergantungan yang sangat besar tersebut yang paling besar dirasakan oleh masyarakat ekonomi kelas bawah, yang persentasenya masih sangat besar bila dibandingkan dengan masyarakat ekonomi kelas menengah dan atas. Tabel di bawah ini layak untuk kita jadikan sebagai salah satu referensi yang membuktikan betapa penduduk ekonomi kelas rendah sangat besar di Indonesia.

Tabel 1. Prosentase Pendapatan di Antara Tiga Tingkatan Pendapatan Penduduk Indonesia, 1984-1993

\begin{tabular}{|c|c|c|c|c|}
\hline \multirow{2}{*}{$\begin{array}{c}\text { Staratifikasi Sosial } \\
\text { Atas Dasar Pendapatan }\end{array}$} & \multicolumn{4}{|c|}{ Prosentase Distribusi pendapatan } \\
\cline { 2 - 5 } & $\mathbf{1 9 8 4}$ & $\mathbf{1 9 8 7}$ & $\mathbf{1 9 9 0}$ & $\mathbf{1 9 9 3}$ \\
\hline $20 \%$ tertinggi & 41,97 & 41,65 & 41,94 & 42,76 \\
\hline $40 \%$ menengah & 37,28 & 37,48 & 36,75 & 36,91 \\
\hline $40 \%$ terendah & 20,75 & 20,87 & 21,31 & 20,34 \\
\hline
\end{tabular}

Sumber: Dumairy, Ekonomi Indonesia, dikutip Afan Gaffar (hal. 188)

Data tersebut menunjukkan bahwa di bidang ekonomi kita mengalami kesenjangan yang sangat mencolok antara kelompok masyarakat Indonesia. Dari tahun ke tahun kesenjangan tersebut bukan semakin berkurang, malah semain memburuk. Sekitar 20\% penduduk berpenghasilan tinggi menikmati sekitar $41,97 \%$ pendapatan nasional pada 1984 . Sebaliknya penduduk berpenghasilan rendah yang jumlahnya mencapai kira-kira 40\% hanya menikmati sekitar 20,75\% dari keseluruhan pendapatan nasional. Angka tersebut tidak berubah secara signifikan sampai tahun 1993, bahkan semakin memburuk.

Data yang sebenarnya sudah agak lama tersebut cukup memberikan bukti besarnya kesenjangan yang terjadi di antara kelompok penduduk dalam masyarakat, serta menunjukkan betapa besarnya jumlah penduduk kelas ekonomi rendah di Indonesia. Walaupun tidak ada data lebih lanjut, akan tetapi bisa kita analisis secara rasional bahwa kesenjangan akan semakin besar sejak pertengahan tahun 1997 Indonesia mengalami krisis moneter yang berimbas pada krisis ekonomi yang lebih luas. Dalam 6 tahun terkhir di beberapa lapangan pekerjaan yang mempekerjakan jutaan tenaga kerja atau buruh telah terjadi pemutusan hubungan kerja (PHK) besar-besaran. 
Kondisi demikian mengakibatkan semakin besarnya ketergantungan masyarakat terhadap negara di bidang ekonomi. Contoh konkrit besarnya ketergantungan masyarakat di bidang ini adalah ketidakmampuan petani untuk bertindak dalam posisi tawar yang kuat dengan patokan harga gabah yang ditentukan oleh pemerintah, sehingga di beberapa tempat seperti Jawa Tengah, para petani tidak bisa menikmati hasil panen mereka, karena murahnya harga jual gabah petani.

Selain itu, terdapat kesenjangan taraf hidup antar kelompok penduduk dalam masyarakat, dalam sekup mikro maupun makro. Hal itu menyebabkan rapuhnya bangunan masyarakat secara horizontal, baik antar satu kelompok masyarakat dengan kelompok masyarakat yang lain, juga dalam sekup yang lebih besar antara satu daerah dengan daerah yang lain.

Untuk menganalisis kesenjangan antara daerah-daerah atau antara kelompok masyarakat yang satu dengan yang lain secara konkrit, misalnya dengan melihat Jakarta dari sudut pandang ekonomi. Jakarta, sebagai ibukota negara dan pusat pemerintahan, dengan segala konsentrasi kekuasaan dan ekonomi di satu pihak, berbeda jauh dengan masyarakat di bagian yang lain yang masih sangat jauh tertinggal, seperti di Papua yang masih bisa dibilang primitif, dan di tempat-tempat yang lain. Kalau kita melihat Jakarta lebih jauh lagi, kota Metropolitan ini penuh dengan dimensi-dimensi kehidupan masyarakat yang serba kontras. Menurut catatan terakhir sebagaimana dalam Afan Gaffar (2000:189), pendapatan per kapita penduduk Jakarta pada tahun 1996 telah mencapai US\$3.600, dengan tingkat Pendapatan Asli Daerah (PAD) mencapai 1,3 trilyun. Di antara orang-orang di Jakarta, ada yang tingkat penghasilannya melebihi penghasilan orang-orang yang telah mengalami pasca industrialisasi, seperti Jepang dan Amerika Serikat, yang income per kapitanya mencapai angka US\$22.000. Orang-orang yang tinggal di daerah Menteng, Kebayoran Baru, Pondok Indah, Bintaro Jaya, Lippo Village, dan Bumi serpong merupakan orang-orang yang super kaya dimana penghasilannya bisa ribuan kali lipat penghasilan sebagian besar penduduk Indonesia, terutama di daerah-daerah terpencil di luar jawa. Sebagai bahan perbandingan untuk melihat betapa besar kesenjangan yang ada, tidak perlu melihat terlalu jauh ke luar Jakarta. Kalau kita keluar dari jalan-jalan protocol saja dan memasuki jalan lorong-lorong perkampungan Jakarta, di daerah sekitar pinggir Kali Ciliwung, akan terlihat jelas sisi lain kota Jakarta, yaitu kehidupan mereka yang tersisihkan secara ekonomi dan politik. Pemandangan yang sama akan juga terlihat di beberapa kota besar kedua di Indonesia, seperti Surabaya, Semarang, Bandung, Surakarta, Malang, Yogyakarta, dan di luar Jawa, seperti Medan, Padang, Pekanbaru. Banjar- masin, 
Ujung Pandang, Denpasar, Mataram, Jaypura, dan lain sebagainya. Selain itu, lebih jauh lagi di pedesaan-pedesaan di Pulau Jawa dan Bali, selanjutnya, pedesaanpedesaan di luar pulau Jawa dan Bali, dan yang paling rendah lagi adalah dan akan semakin rumit kalau kita memasukkan dalam pengamatan tentang civil society, yaitu kelompok masyarakat yang tinggal di pedalaman Papua, Kalimantan, dan sebagian pulau Sumatera dan Sulawesi.

Konfigurasi demikian berimplikasi pada konfigurasi representasi masyarakat di bidang politik, yaitu kecenderungan sentralisasi kekuasaan di Pusat Pemerintahan. Rekrutmen politik yang dilakukan setiap lima tahun selalu menghasilkan ketidakseimbangan figur politik yang terpilih sebagai hasil pemilihan umum, yang tidak secara proporsional menggambarkan representasi keseluruhan masyarakat Indonesia yang heterogen dari Sabang sampai Merauke.

Di samping itu mengembangkan civil society juga dihadapkan pada tantangan dalam ranah sosial dan politik dimana rakyat sampai saat ini masih sangat kental dengan budaya paternalistik. Ketokohan seseorang dalam sebuah entitas sosial harus diakui masih melekat pada warga masyarakat. Dalam kecenderungankecenderungan politik misalnya, loyalitas rakyat bahkan seringkali mengalahkan rasionalitas.

Atmosfir perilaku voters dalam Pemilu 2004 yang menggambarkan budaya paternalistik masih juga kentara. Pengaruh elit baik di tingkat lokal maupun nasional masih sangat besar terhadap polarisasi pilihan politik pemilih. Kalaupun pada Pilpres putaran pertama yang lalu banyak pemilih yang seakan-akan otonom dari kebijakan partai politik di tingkat nasional, hal itu sebenarnya tidak bisa di pandang sebagai fenomena lunturnya budaya paternalistik mengingat sangat sulit untuk mengidentifikasi apakah sekelompok pemilih itu merupakan massa atau kader partai politik tertentu atau bukan. Bahkan lehi dari itu sesungguhnya sedikit banyak pilihan politik mereka banyak ditentukan oleh pengaruh elit di tingkat lokal.

Kentalnya budaya paternalistik ini merupakan salah satu tantangan bagi terwujudnya civil society. Sebab, keterbukaan warga negara atau masyarakat dalam merespon sebuah wacana atau kebijakan yang terkait dengan kepentingan politik akan banyak ditentukan oleh pengaruh elit atau figure tertentu yang mereka segani, bukan oelh otonomi yang berlandaskan pada rasionalitas. 


\section{Kesimpulan}

Sebagai catatan penutup makalah ini dapat direduksi beberapa konklusi, di antaranya: Pertama, masa depan demokratisasi di Indonesia sangat ditentukan oleh terwujudnya civil society, yaitu masyarakat dalam negara yang di dalamnya terdapat asosiasi-asosiasi sosial yang mampu mengisi ruang publik antara masyarakat dengan negara serta berinteraksi dengan negara secara independen, baik secara individual maupun kolektif.

Kedua, Prospek pengembangan civil society di Indonesia ditentukan oleh faktor pembentukan dan penguatan beberapa komponen-komponen di dalam kehidupan bermasyarakat dan bernegara, yaitu ; otonomi, akses masyarakat terhadap lembaga negara, Arena publik yang mandiri dan arena publik yang terbuka. Di samping itu prospek pengembangan civil society juga sangat ditentukan oleh optimalisasi beberapa faktor, diantaranya: penciptaan keluarga demokratis, peningkatan peran organisasi non pemerintah, optimalisasi peran kelas menengah intelektual, khususnya mahasiswa, dan pendidikan politik.

Ketiga, proses pembentukan civil society dalam konteks Indonesia dihadapkan pada beberapa tantangan, di antaranya; tingginya fragmentasi sosial di tengahtengah masyarakat, belum meratanya hasil pembangunan di bidang ekonomi, sosial dan pendidikan, serta masih kuatnya budaya politik paternalistik di dalam masyarakat.[*] 


\section{Daftar Pustaka}

Afan Gafar. 2000. Politik Indonesia Transisi Menuju Demokrasi. Yogyakarta: Pustaka Pelajar

Anthony Giddens. 2000. Tbe Tbird Way. Jakarta: PT. Gramedia Pustaka Utama

Arbi Sanit. 1985. Swadaya Politik Masyarakat. Jakarta: Rajawali Press

John A. Hall. 1995. Civil Society: Theory, History, Comparison. Massachussets: Plity Press

Liang Gie. 1974. Ilmu Politik. Yogyakarta: Gadjah Mada Press

Mahfud MD. 1999. Pergulatan Politik dan Hukum di Indonesia. Yogyakarta: GAMA MEDIA

Miriam Budiarjo. 1999. Dasar-dasar Ilmu Politik. Jakarta: PT. Gramedia Pustaka Utama

Nur Khoirun, dkk. 1999. Pendidikan Politik Bagi Warga Negara. Yogyakarta: LKiS

Robert A. Dahl. 2001. Peribal Demokrasi Menjelajabi Teori dan Praktek Demokrasi secara singkat. Jakarta: Yayasan Obor Indonesia

. 1985. Dilema Demokrasi Pluralis. Jakarta: Rajawali Pres

Rusli Karim. 1987. Esei-esei Politik Indonesia Kontemporer. Yogyakarta: Emerka

Solichin Abdul. 1989. Analisis Kebijakan Negara. Jakarta: Rajawali Press 